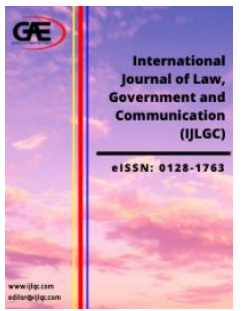

\author{
INTERNATIONAL JOURNAL OF LAW, \\ GOVERNMENT AND COMMUNICATION \\ (IJLGC) \\ $\underline{w W w . i j l g c . c o m}$
}

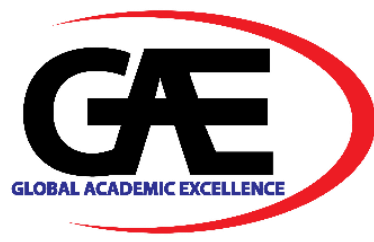

\title{
NATIVE COURT IN KUDAT AND MATUNGGONG, SABAH: CHALLENGES TO ITS GOVERNANCE AND STRUCTURAL ECOSYSTEM
}

Rosazman Hussin ${ }^{1 *}$, Johan Johnes ${ }^{2 *}$, Jabil Mapjabil ${ }^{3}$, Jeannet Stephen ${ }^{4}$, Jurry Foo @ Jurry Bt. F. Michael $^{5}$, Zaini Othman ${ }^{6}$, Baszley Bee Basrah Bee ${ }^{7}$

1 Borneo Institute For Indigenous Studies \& Faculty of Social Sciences and Humanities, Universiti Malaysia Sabah, Malaysia

Email: azzs@ums.edu.my

2 Borneo Institute For Indigenous Studies \& Faculty of Social Sciences and Humanities, Universiti Malaysia Sabah, Malaysia

Email: johanjohnes28@gmail.com

3 Borneo Institute For Indigenous Studies, Universiti Malaysia Sabah, Malaysia

Email: jabil@ums.edu.my

4 Borneo Institute For Indigenous Studies \& Centre for the Promotion of Knowledge and Language Learning, Universiti Malaysia Sabah, Malaysia

Email: jeannets@ums.edu.my

5 Center for Co -Curriculum and Student Development, Borneo Institute For Indigenous Studies \& Faculty of Social Sciences and Humanities, Universiti Malaysia Sabah, Malaysia

Email: jurryfm@ums.edu.my

6 Faculty of Social Sciences and Humanities \&Borneo Institute For Indigenous Studies, Universiti Malaysia Sabah, Malaysia

Email: zo@ums.edu.my

$7 \quad$ Faculty of Social Sciences and Humanities \&Borneo Institute For Indigenous Studies, Universiti Malaysia Sabah, Malaysia

Email: baszley@ums.edu.my

* Corresponding Author

\section{Article Info:}

\section{Article history:}

Received date: 03.08.2021

Revised date: 19.08.2021

Accepted date: 16.09 .2021

Published date: 19.09.2021

\section{To cite this document:}

Hussin, R., Johnes, J., Mapjabil, J., Stephen, J., Michael, J. F., Othman, Z., \& Basrah Bee, B. B. (2021). Native
Abstract:

The Sabah Native Court is a legal institution created specifically to address the application of customary law among the ethnics or indigenous peoples of Sabah. Sabah Native Court is a legal institution established by a special act known as the Native Courts Enactment 1992 amendment 1995. The purpose of this study was to identify the challenges to the governance and structural ecosystem of native courts in selected districts, specifically Kudat District and Matunggong Sub-district. This study uses qualitative methods through in-depth interviews with district heads in these two native court. Among the study's interesting findings is the hierarchy of the organisational structure of the native court institution found in both study locations, which has differences in the number of staff appointments either at the decision-making level for district 


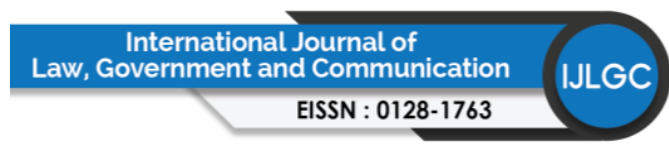

Volume 6 Issue 25 (September 2021) PP. 94-113

DOI 10.35631/IJLGC.625009

Court in Kudat and Matunggong, Sabah: Challenges to Its Governance and Structural Ecosystem. International Journal of Law, Government and Communication, 6 (25), 94-113.

DOI: $10.35631 /$ IJLGC.625009.

This work is licensed under $\underline{\text { CC BY 4.0 }}$ (1)(1) head or among native court implementers such as native chiefs and deputy native chiefs. Furthermore, the two study locations have different day-to-day governance and assignment for every entity within the native court. Questions about the benefits and drawbacks of challenges to both governance and the structural ecosystem of the native courts in both study locations were also addressed in the discussion section. Due to its importance in monitoring these challenges, this study will examine how well the native courts can resolve the concerns of each ethnic in the state compared to other judicial institutions such as the Syariah Court and Civil Court.

Keywords:

Structural Ecosystem, Governance, Native Court, Kudat, Matunggong SubDistrict

\section{Introduction}

Borneo's indigenous or natives are referred as the "Anak Negeri" in Malaysia's states of Sabah, Sarawak, and Federal Territory of Labuan. According to the federal constitution, all natives are considered Bumiputera Malaysia, but not all natives are considered Bumiputera Malaysia (Berita Harian, February $9^{\text {th }}$, 2019). According to James (2003), the use of "Anak Negeri" terms is directly related to the early history of Malaya, Sabah, and Sarawak forming Malaysia federation, as well as the Government's policy of Islamization and Malaynization under Tun Datu Mustapha bin Datu Harun (3rd Chief Minister of Sabah) and Tan Sri Datuk Seri Panglima Harris bin Mohd Salleh (6th Chief Minister of Sabah). According to him, the indigenous people of Sabah, particularly ethnic KadazanDusun, see the government's use of the term "indigenous" as an attempt to unite all ethnic groups in Sabah with the natives of Peninsular Malaysia, which is dominated by Malays. "Native" is a term widely used to refer to Sabah Bumiputera. Therefore, all government agencies that administer Sabah Bumiputera affairs are named "Native" such as Native Courts, Sabah Native Affairs Office, and Sabah Native Affairs Council. Legally speaking, the word "Anak Negeri" under state legislation is translated literally into English as "native" (Pg Ismail et al., 2018).

The definition of a native varies depending on the state. Section 2(1) of the Interpretation (Definition of Native) Ordinance 1952 defines the term "native" in Sabah to mean one of two things:

a) any person both of whose parents are or were members of a people indigenous to the Sabah; or

b) any person ordinarily resident in Sabah and being and living as a member of a native community, one at least of whose parents or ancestors is or was a native within the meaning of paragraph (a); or

c) any person who is ordinarily resident in Sabah is a member of the Suluk, Kagayan, Simonol, Sibutu or Ubian people or a people indigenous to the State of Sarawak or the State of Brunei, has lived as and been a member of a native community for a continuous period of three years preceding the date of his claim to be a native, has borne a good character throughout that period and whose stay in Sabah is not limited under any of the provisions of the Immigration Act, 1959/63; or

d) any person who is ordinarily resident in Sabah, is a member of a people indigenous to the Republic of Indonesia or the Sulu group of islands in the Philippine Archipelago or the States of Malaya or the Republic of Singapore, has lived as and been a member of a native community for a continuous period of five years immediately preceding the 


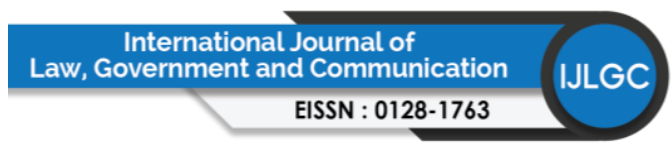

Volume 6 Issue 25 (September 2021) PP. 94-113

DOI 10.35631/IJLGC.625009

date of his claim to be a native, has borne a good character throughout that period and whose stay in Sabah is not limited under any of the provisions of the Immigration Act, $1959 / 63$.

There are now many Sabahans with a higher education who work in the cities in the government service, business or academia; yet many of them remain connected to their hometowns and continue to uphold the traditions and respect the customary law that has been passed down for generations (Pugh-Kitingan, 2015). Today, the native courts in every area are based on indigenous customary law. Led by Native Judges, the native court is one of the three Malaysian judicial systems, the other two being the High Court for civil cases and the Syariah Court for Muslims (Miyamoto 2008). This study examines the structural ecosystem found in selected districts, namely Kudat District and Sub-District of Matunggong, as well as the challenges in aspects of governance of the native courts in both study locations.

\section{Literature Review}

\section{Structural Ecosystem of Sabah Native Courts}

Other Southeast Asian countries, including Thailand, Myanmar, Indonesia, and Vietnam, have indigenous administrative institutions (Mosli, 2009; Morton, 2017; Hamzah, 2018). According to Dahm (1988), indigenous administrative institutions in Indonesia are led by people known as Kepala Desa or Lurah. They are in charge of the indigenous community's affairs and are the keepers of the indigenous customary system. Tok Batin, the leader of the Orang Asli community in peninsular Malaysia, is one of the indigenous administrative institutions that is still operational. Tok Batin is in charge of preserving and safeguarding the tribe's peace, as well as acting as a contact person with the outside community. He also has the authority to define and establish tribal regulations, as well as to punish members who violate them (Official Website of the Department of Arts \& Culture, Malaysia, 2020).

Meanwhile, according to Hooker (1980), when Baron Overbeck and Alfred Dent Esquire obtained North Borneo from the governments of Brunei and Sulu in 1881, they discovered two laws or lex loci in North Borneo (Sabah). These laws are the pagan customary law of Sabahans who primarily dwell in Sabah's interior, and Islamic law for Muslim locals who mostly live on the West and East Coasts of Sabah (Hooker, 1980; 1976, Muhidin, 1990). Native court is a judicial entity that existed from 1881 to 1946 when the British North Borneo Company occupied the state (Rafidah @ Malissa, 2014). The native court system is separate from the Syariah Courts and Civil Courts since it was established by the native courts Enactment of 1992.

According to Rafidah @ Malissa (2014), upon independence, the Sabah State Government established the Sabah Bumiputera Affairs Unit. This section is in charge of supervising the native court's customs, disputes, and administration based on Sabah Native Affairs Council Enactment of 1998. Beginning in 1999, this Unit was updated and turned into the Sabah Native Affairs Council, a statutory organization based on the Sabah Native Affairs Council Enactment 1998. The Council's big priority is to advise the State Government on all topics concerning the legal system and indigenous customs in Sabah, to research diverse indigenous customs, and to evaluate indigenous customary law on a regular basis. The Council is made up of a President, State Secretary, Attorney General, Permanent Secretary of the Ministry of Local Government 
Volume 6 Issue 25 (September 2021) PP. 94-113 DOI 10.35631/IJLGC.625009

and Housing, a Secretary, and six additional members who are experts in Sabah's customs and customary laws.

Meanwhile, the native court system has three tiers namely Native Court, District Native Court, and the Native Court of Appeal (Rafidah @ Malissa, 2014; Pg Ismail et al., 2018; Rosazman et al., 2021). The three courts were formed according to the requirements to resolve matters of customary law. It is necessary to create a native court of appeal if the matter cannot be settled by the native court or district native court. Figure 1 shows the structural ecosystem within the Sabah Native Court.

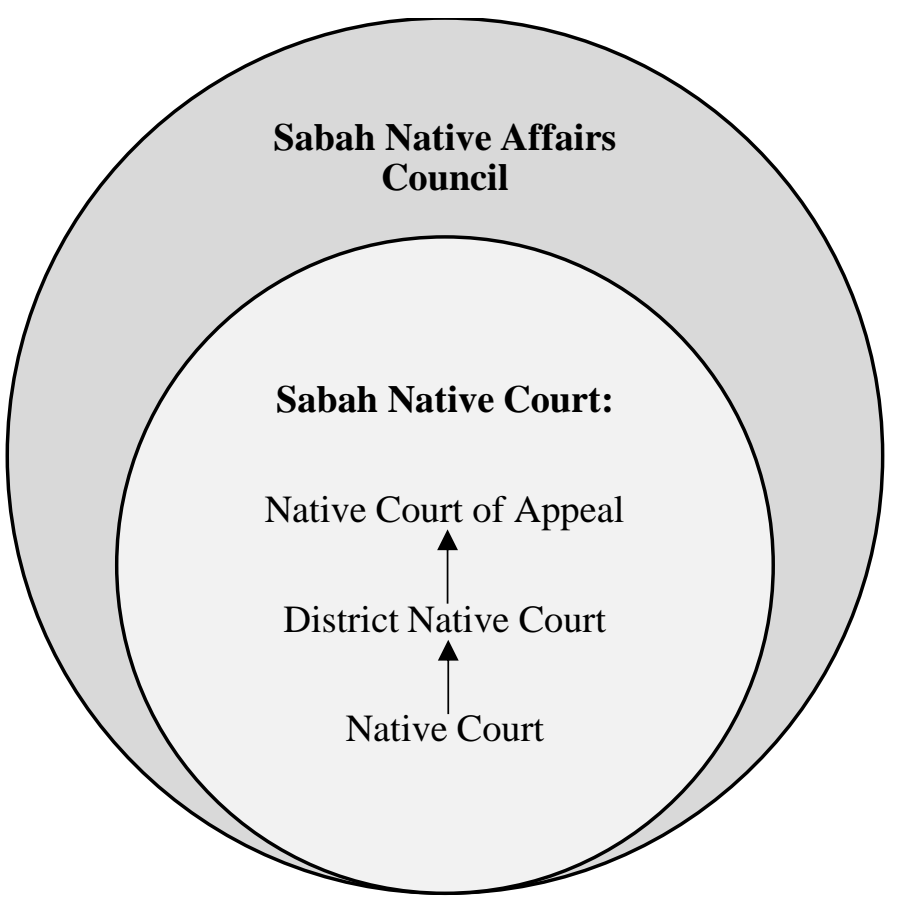

Figure 1: The structural ecosystem in the Sabah Native Courts.

Source: Researcher adaptation (2021).

Native Courts (Criminal Jurisdiction) Act 1991 stipulates that such violations can be punished with a fine of up to five thousand Ringgit (RM5, 000.00) or two years of imprisonment, or both. Apart from these penalties, the Native Courts (Native Laws) Rules 1995 have also provided for various types of customary fines as follows (Table 1):

Table 1: Various Types of Customary Fines

\begin{tabular}{ll}
\hline $\begin{array}{l}\text { Types of customary } \\
\text { fines }\end{array}$ & \multicolumn{1}{c}{ Explanation } \\
\hline Sogit & $\begin{array}{l}\text { A customary penalty (in the forms of livestock animals) that } \\
\text { functions as compensation that will 'cool' or 'heal' the person } \\
\text { or place who or which was wronged by violations of the } \\
\text { customs. }\end{array}$ \\
& $\begin{array}{l}\text { A customary penalty for affair between a married man and a } \\
\text { married woman, or between a married man and a woman who is } \\
\text { still single. } \\
\text { The offer of peace according to the customs of the aggrieved } \\
\text { party so as to maintain peace and friendship. }\end{array}$ \\
\hline
\end{tabular}


Volume 6 Issue 25 (September 2021) PP. 94-113 DOI 10.35631/IJLGC.625009

Denda Adat

Denda malu

Kepanasan kampung

Koimanan

Kosoguluanan
A penalty imposed according to the customs of the natives or local customs in the district where the Court is established. means a customary compensation in respect of any breach of native customary law which exposes the aggrieved party to the possibility of disgrace.

means a customary fine in respect of an offence against the general virtues and dignity of a village.

means a loss or damage suffered by reason of a breach of promise to perform a certain act;

means any marriage of a person who marries before an elder brother or sister.

Source: modified from Pg Ismail et al., (2018) and Native Courts Enactment (1992)

\section{Governance of Sabah Native Court}

\section{Requires Good Governance of Sabah Native Courts}

There are many perspectives in determining the characteristics or principles of good governance by various scholars such as the international financial or donor institutions (Rhodes, 2000; Rhodes, 1997; UNDP, 1997). UNDP (1997) explained that the characteristics or principles developed for the implementation of good governance are: 1) participation, 2) rule of law, 3) transparency, 4) responsiveness, 5) consensus orientation, 6) equality, 7) effectiveness and efficiency, 8) accountability and 9) strategic vision. In this study, we adapted the definition of good governance i.e. a method or system of governing, administering, and regulating a policy, function, or operation of a corporation, organisation (Rhodes, 2000) that involves "an efficient public service, an independent judicial system and legal framework to enforce contracts; the accountable administration of public funds; an independent public auditor, responsible to a representative legislature; respect for the law and human rights at all levels of government; a pluralistic institutional structure, and a free press (Leftwich, 1993; Leftwich 1994; Rhodes, 2000). Therefore, in this study, governance in native courts is separated into two levels: governance at the village level and governance inside the premises of the native court building or the District native court involved (Rosazman et al., 2021). At the village level, the village head is generally involved in the village's activities, whether it's making a report or any other significant topic that demands the village head's attention. Governance at the native court level involves the villagers' requests for document verification, attendance at trials, and involves the division of duties and working time among staff in the native court, especially district heads, native heads and deputy native chiefs. In general, Rosazman et al. (2021) highlighted the lack of a distinctive governance guide in the administration of Sabah Native Courts and that each native court has its own system of files maintenance and distribution of daily tasks.

Therefore, the challenges or problems faced by Sabah Native Courts, according to Rafidah @ Malissa and Syuhaeda Aeni (2019), are records of trial proceedings which are rarely archived at the native chief or village head level. In addition, evidence at such proceedings is given verbally in an informal manner, and judgements are typically rendered orally. Moreover, knowledge of these information is limited to the district or village due to no stipulation by the Native Court Ordinance that it can enforce the archiving of documents (Syed Ahmad Idid, 1993). Also, the absence of formal guidelines also makes it difficult for the native chiefs and village head to see a suit in its perspective as a potential appeal within the formal system 


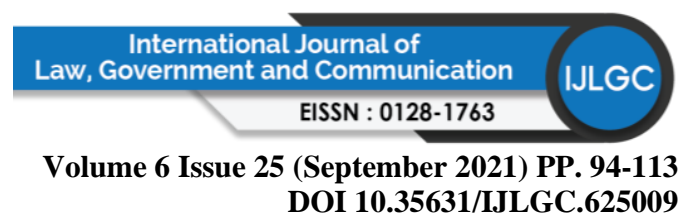

(Rafidah @ Malissa \& Syuhaeda Aeni, 2019). Furthermore, there is also concern over the appointment of a native court officer. According to Section 2 of the Native Court Enactment 1992, a native chief is someone appointed by the State Public Service Commission, whereas a district head is also someone appointed by the State Public Service Commission. However, as Rafidah @ Malissa and Syuhaeda Aeni (2019) point out, even though the appointment is conducted by the State Public Service Commission, there is some political intervention in the appointment and removal of native court officers. Unfortunately, the native court has now become a venue for political vengeance and backbiting (Raymond, 2009).

Sabah Native Courts were also not provided with an appropriate building in every district. This posed a difficulty for their administration. Nowadays, several of the native courthouses are based in the District Office building but there are still native courts that must begin hearings at balai raya or community halls due to a lack of a suitable venue for the court to hear cases (Rafidah @ Malissa \& Syuhaeda Aeni, 2019). But for certain District Native Courts that have their own premises, problems such as a lack of support staff arise due to a lack of funds (AsiaPacific Human Rights Information Center, 2019). Another government challenge that native court must address is consistency in workforce management and understanding as well as practise of traditions by current younger leaders, since the future preservation and adherence of customs is highly dependent on their actual practise. Having said that, it would be far preferable to have a clearer and proper system of administering the governance of the Sabah Native Court for the future.

\section{Methodology}

This is a case study that looked at the governance and structural ecosystem of the Sabah Native Courts. This study took a qualitative approach employing in-depth interview procedures to obtain information from the informants. Zelditch (1979) states that in-depth interview approaches are the most effective methods to gain qualitative data. The information provided by the informants is crucial to the study's findings. Word-for-word transcriptions of relevant replies will be made available to the public (Jasmi, 2012). The study concentrated on two native courts namely the Kudat Native Court and the Matunggong Native Court (Figure 2). 
Volume 6 Issue 25 (September 2021) PP. 94-113 DOI 10.35631/IJLGC.625009

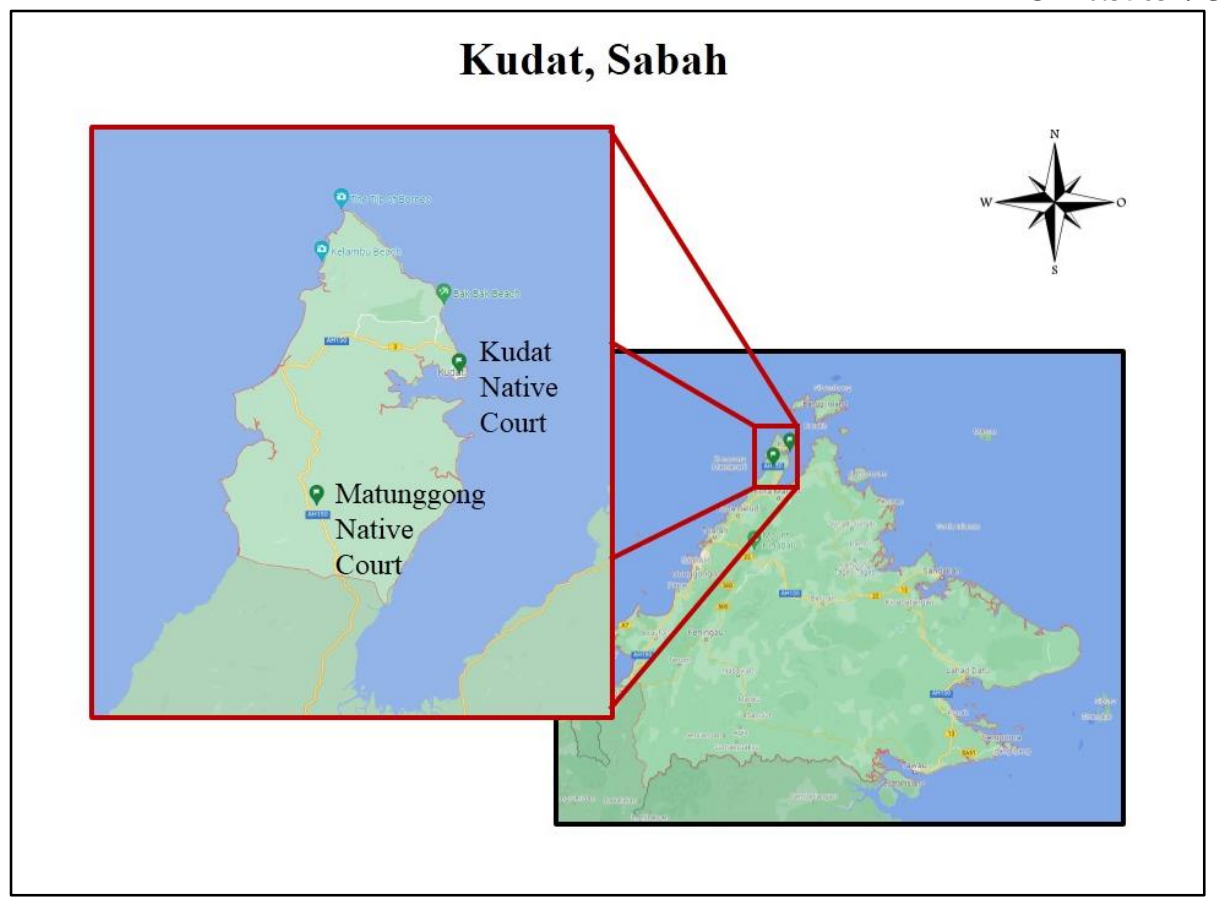

Figure 2: Study Area Map

Source: Google Maps (2020).

The Kudat Native Court has three district heads while there is only one district head for the Matunggong Native Court. However, only two district heads from the Kudat Native Court and one from the Matunggong Native Court participated in this study. Data presentation and discussion was based on a comprehensive evaluation of the interview transcripts. The data obtained from the two native courts involved was divided into particular topics to make it simpler to grasp. Following that, the study's findings, which have been split according to these topics, are examined in greater detail in the discussion section and thereafter used as the basis in the authors' recommendation for a more successful structural ecosystem and governance of the native courts.

\section{Research Findings}

Following the in-depth interviews the study revealed that the challenges in the governance and structural ecosystem governance observed in these two native courts are quite similar. This is because the background in the respective native courts' district heads are comparable. The following are further analyses on the research findings.

\section{Structural Ecosystem and Services of the Native Courts}

\section{The Native Courts Provide Services for Both Non-Muslim and Muslim Clients}

The great majority of cases heard in the native courts, according to Informant 1 below, are specifically from among the non-Muslim community.

"..The majority of the cases here are specifically for non-Muslims, such as engagement, marriage, divorce, child adoption, and inheritance.." (Informant 1) 


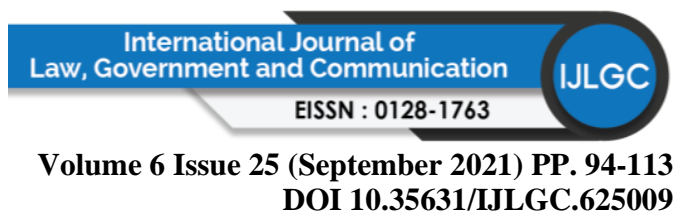

However, according to Informant 1, there are Muslim communities who also use the native court services as follows:

“..There are a few Muslims, for example, who do not have a marriage certificate and have their marriage only validated by the village head. Assume the role of the village head, who is in charge of the village. We assisted the village head since he requested assistance with the marriage certificate.." (Informant 1)

When asked on the target group of the native courts ecosystem, the informant said that native courts were designed to tackle native custom-related cases among non-Muslims. This was reported by Informant 1 as follows:

"..However, the major attention is on the matter of non-Muslims, which is addressed and regulated by the native court.." (Informant 1)

As seen in Table 1, the majority of native customary law under the Native Courts (Criminal Jurisdiction) Act 1991 is open-ended and not contradictory to religious beliefs. As a result, all Sabahans regardless of faith can approach the Native Courts for some cases. Nonetheless, cases involving Muslim locals are nowadays handled by the Syariah Court. This is also supported by the definition of a native which does not state that religious factors limit a person from being a native who can utilise the native court.

\section{Limitation of Knowledge and Experience Among Native Court Staffs.}

When queried about the laws in the Sabah Native Courts, Informants 1 and 3 claimed that they had only recently taken over the position and wanted to learn more about the Sabah Native Court Enactment 1992. Informant made the following statement:

"..I've only been employed for eight months. The true mission of the native court is to protect the indigenous customs established by the Sabah State Government.." (Informant 1).

“..This is something that I myself do not yet understand since, as previously said, I am too new and, at the moment, I am simply performing my job. Again, the entire thing remains hazy.." (Informant 3).

As underlined by Rafidah @ Malissa and Syuhaeda Aeni (2019), the appointment of a staff in the native court should take into consideration experience and degree of expertise in order to retain natives' understanding and sense of belonging to their customs. Furthermore, choosing someone with less expertise and understanding of indigenous customary law would cause inefficiencies in the the court's day-to-day operations since the chosen individual will require time to comprehend and fulfil the responsibilities allocated to them.

\section{The Forms and Intepretation of Customary Laws Used by Native Court in Each District are Different}

In terms of the application of customary laws in the Sabah Native Courts, the informants indicated that any type of customary laws adhered to in each district varies according to the customs of the ethnic communities in the district. This is discussed in detail below:

“..Each ethnic creates its own legislation. Molbog has already been written, while Iranun, KDMR (Kadazan, Dusun, Murut, Rungus), and other ethnicities 


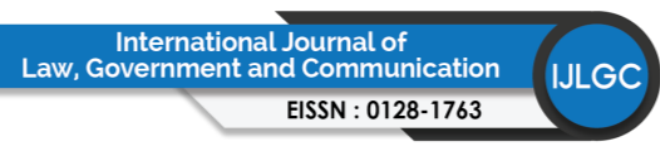

Volume 6 Issue 25 (September 2021) PP. 94-113

DOI 10.35631/IJLGC.625009

are still in the works. We have previously produced 19 books on ethnic groups' customary law.." (Informant 1).

"..Perhaps in the month of October of 2019, we will release a book on customary law for Rungus ethnics. There was one before this, but I believe the book is insufficiently thorough and incomplete.." (Informant 3).

Efforts to record customary law for each ethnic community in Sabah are extremely beneficial in terms of reference to action that has to be taken for each violation of native custom during the native court trials. The Sabah Native Affairs Council can supervise the preparation and quality of this book to ensure that it meets the quality and appropriateness for use as a reference in a native court trials. Indirectly, the availability of these customary law books will make it simpler for the public and researchers to refer to them for purposes such as evaluating the penalties imposed for a customary violation or as research material.

\section{Political Influences in The Appointment of Native Court District Heads}

Informants 2 and 3 indicated that their appointments were influenced by political considerations, as mentioned below:

"This appointment is proposed by Yang Berhormat (YB) here. This means that the Warisan committee and this name was sent to the Ministry of Law for appointment.." (Informant 2).

"..so when examined there may be more to Warisan so that can be seen that there is indeed a recommendation from the party leader,... the views from the assistant officer here is also necessary to recommend who is going to be appointed.." (Informant 3).

Furthermore, there were formerly only two district heads appointed to the Kudat Native Courts but now there are three persons which might be owing to the support of some people for the political leader in their district. Informant 2 stated this as follows:

"In Kudat, previously there were two district heads, before that there were two more. Now there are three district heads, I am not sure why. Probably the pressure to support YB. Let's say YB Ben Chong wins, he appoints his people.." (Informant 2).

Moreover, according to the third informant, native court appointments are not just dependent on eligibility criteria but also on the leadership of the prevailing political party. Here's what Informant 3 had to say about this:

“..this appointment is actually not evaluated based on merit alone but when the new government rules, they have a different method than the others.."

"..for example, if in Matunggong there are four parties, namely WARISAN, $P K R, D A P$ and $P B S$, it is suggested that all this parties other than the ruling parties (WARISAN) has an allocation that is limited only for the native chief seats. So WARISAN has three native chief, then the others have two or three.." (Informant 3).

According to Ahadin (2015), indigenous people criticise the native courts because the appointment of court members is affected by political reasons. Even Lenny et al. (2017) state that the candidates for native chiefs are chosen from among those nominated by the elected Copyright (C) GLOBAL ACADEMIC EXCELLENCE (M) SDN BHD - All rights reserved 


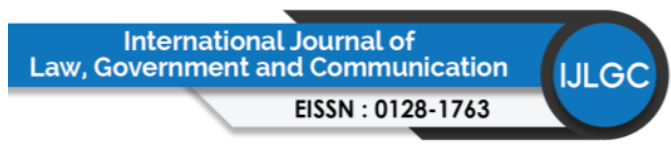

Volume 6 Issue 25 (September 2021) PP. 94-113

DOI 10.35631/IJLGC.625009

representatives of each district. As a result, there is no disputing that political influences exist in the selection of native chiefs for the native courts.

\section{Native Courts Courses and Training}

The informants stated that the Ministry of Law and Native Affairs (until it was repealed and the native courts' jurisdiction was transferred back to the Ministry of Local Government for Sabah) organises courses for each native court in Sabah, as well as training for village heads. This is according to Informant 3:

“..This year, a number of meetings and courses have been held, the first of which was held at ILMAN (Native Court Training Institute) with the Native Courts, bringing together all of the district heads.."

"..There is one on our level, and we have scheduled one for the village head.." (Informant 3).

The Sabah Native Affairs Council, as a body that monitors and assesses the relevance and requirements of native courts in sustaining the continuity of customary laws in Sabah, must be more aggressive in ensuring that native court employees are trained in the responsibilities given to them. Furthermore, as indicated by Informant 3, auxiliary measures such as providing workshops on customary law in each native court must be held more often and in all native courts in Sabah. As one of the courts accessible in Malaysia, this would indirectly aid to improve the quality of native court services.

\section{The Governance-related Issues of Sabah Native Courts}

\section{Diverse Native Court Administrative Structure Between Districts}

The nature of native court governance in Kudat and Matunggong is virtually entirely different and diverse. There are three district heads chosen in Kudat, but there is no one leader who governs the whole government. Informant 2 reported this as follows:

"..If there are three, there must be a leader; with the leader present, all duties will be at the same level. If we look at the schedule, we can see that the form of our job is the same; sometimes the headquarters is due to the specialty of the task, but nothing is put down orally.." (Informant 2).

Matunggong's native court district head is only one person, according to the Informant 3:

"..Here there is only one person as the district head and the native chief.."

(Informant 3).

The variation in the organisational structure of the native courts are attributed to a lack of clear standards on the number of appointees for a post. For certain districts, the district head is appointed based on the demands of the area of responsibilities, such as the district head for trial duties, the district head for administrative tasks, and so on. There are also native courts that delegate decision-making authority to a single district head. In several other districts in Sabah, district heads are divided based on religion, with district heads for Islam and religious heads for non-Muslim religions. This has resulted in a lack of consistency across the native courts as well as inefficiencies in the courts' administration. 


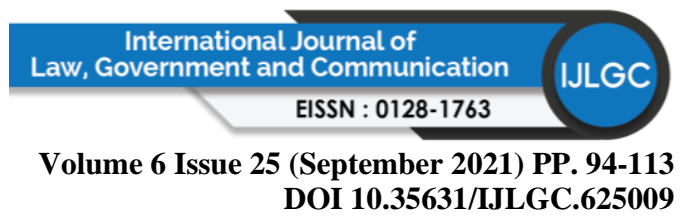

\section{Differences in Organisational Structure and Governance Between Districts}

In terms of the governance organisation chart, the two native courts in this study have different governance organisation charts. The Kudat Native Court, according to informant 1, is organised as follows:

"..we have three district heads, five native chiefs, 15 deputy native chiefs and leaders in each village or settlement consisting of village heads and chinese community leaders.." (Informant 1).

Meanwhile, the Matunggong Native Court has a different organisational chart. According to Informant 3, their organisational structure is as follows:

"..we have one district head, seven native chiefs, 11 deputy native chiefs and village heads from all villages in the Matunggong sub-district.." (Informant 3).

This is due to several needs, such as the number of appointments for native heads, which is dependent on the type of matters found in native courts (Rosazman et al., 2021). Marriage, divorce, heir claims, adoption, and trials for infractions of customary law among indigenous people are all included in this category. Meanwhile, the number of personnel for the post of deputy native chief is typically decided by the number of mukims in a region. This is because, in the case of a resignation or death among the village heads, the deputy native chief will be accountable as acting village head for any village under his authority (Rosazman et al., 2021).

\section{Lack of Operational Staffs and Sufficient Budget for Both Native Courts}

The researchers found that neither native court has any specific workers or staff tasked to do clerical and cleaning responsibilities in either of the native courts offices involved. There are also no security guards posted to monitor the entrances to these two Courts' buildings. According to Informant 3, they had to execute the duty themselves in turn owing to a scarcity of clerks, housekeeping, and security personnel. The following is how the situation is explained:

"..we have no clerk and borrow one from the district office for two or three days a week to help us with our clerical job, but it's not ideal.."

“..I cleaned this room since I don't like it when my staff sweeps my office, and I don't think I deserve an office cleaner. There are no cleaning staff here, so I cleaned the toilets with the help of a native chief, who said it was fine and we cleaned together.."

“..There is no security guard stationed here. This is something we occasionally say, that this area should be a secure place.." (Informant 3).

According to the Asia-Pacific Human Rights Information Center (2019), native courts with their own facilities do face a shortage of support workers owing to a lack of funding. This is demonstrated in this study by the fact that both native courts involved have their own buildings and do not employ clerks, as well as having difficulty cleaning the court premises due to a lack of funds to hire cleaning staff. Worse, despite having its own building, there are no security guards on duty to ensure the building's safety. 


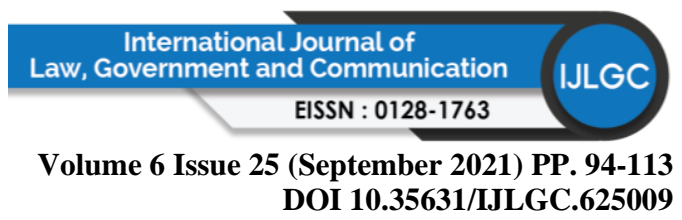

\section{Inadequate Filling System and Building Maintenance}

Due to the following limitations neither native court was able to properly manage the native court building or maintain its files. Information 3 confirms that the Matunggong's native court has been broken into once before:

\section{"..There would be a loss of files during the changeover period because there is no permanent clerk at this premises.." (Informant 2). \\ "..our fence is also often entered by the people around this area, so we are afraid in the future, one day maybe something will happen. Because I was told that this place was broken into once before.." (Informant 3).}

Files were frequently lost or misplaced as a result of the change of administration and the absence of regular clerks in the native courts. For a few clients who came to deal with the native courts, this resulted in delays in concluding their cases. Even the lack of security personnel as a result of the inadequate maintenance budget has resulted in native courts being broken into. The inadequacies and security issues may be prevented if good governance is followed in the native court's premises and the budget for the administration of the premises is increased to ensure the security and secrecy of the courts' files and assets.

\section{Discussion and Evaluation}

Based on the above research findings of the study found several aspects in governance and structural ecosystem of the native courts in this study that can be further discussed.

\section{The Native Courts' Structural Ecosystem and Services}

The level of knowledge of the district heads on the basics of native courts, the diversity of customary laws and appointment issues in the native court is inadequate.

\section{Basics Knowledge of District Heads Regarding to The Native Courts Enacment}

Native court judges should be appointed by the state government based on their understanding of local customs and traditions (Jannie Lasimbang, Former Ministry of Law and Native Affairs of Sabah). It is critical to maintain the indigenous judicial system and preserve indigenous peoples' rights. To guarantee that Native judicial systems are respected, she believes it is preferable that district heads and native chiefs no longer be appointed based on political reasons. Because the district heads designated in this research are still new, having only been in office for less than a year, their capacity to explain the differences between native courts before and after the implementation of the Native Court Enactment 1992 is limited. Their responses are sufficient based on their expertise managing many cases over their appointment period. However, when researchers ask more in-depth questions regarding customary laws, they were unable to provide adequate answers. This situation is not parallel to the meaning of a good governance in term of effectiveness and efficiency offered by Leftwich (1994), UNDP (1997), and Rhodes (2000).

\section{Diversity of Native Court Laws}

The laws implemented in native courts differ from those used in other judicial institutions, such as the Civil Court or the Syariah Court, because they are based on customary laws that have been passed down from generation to generation among specific ethnic communities. The origins of Native Law, according to Rafidah @ Malissa and Syuhaeda Aeni (2019), include the following: (i) Official laws of the government known as statutes or ordinances or proclamations or enactments and rules made thereunder which incorporated and legalized native customs; (ii) 


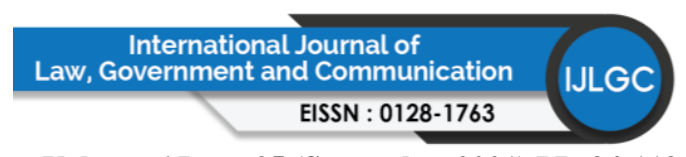

Volume 6 Issue 25 (September 2021) PP. 94-113

DOI 10.35631/IJLGC.625009

Written collections of native laws known as codes which were printed for purposes of administration but which were not legally binding; (iii) Past court cases which have been recorded and which serve as precedents for the present and future time; (iv) Unrecorded oral traditions.

Despite the fact that the violations committed are the same, the punishments or fines imposed vary depending on the customary law established in the district where each customary violation occurs. Non-Muslims, on the other hand, are increasingly using native courts for trial. Meanwhile, the local Sabah population that is Muslim or has converted to Islam will most likely refer to the Syariah Court. So, the diversity of native court laws can be seen in these two native courts since more than one customary law is employed, such as Rungus customary law, Molbog customary law, and Bajau customary law.

\section{Appointment Issues in Native Courts}

The words "District Head" and "Native Chief" are defined in Section 2 of the Native Courts Enactment 1992 as those appointed by the State Public Service Commission. However, in most situations, native court officials are appointed on the advice of State Assemblymen, and there is no institution to examine the qualifications or assess the ability of candidates for administrative posts (Rafidah @ Malissa, 2014). According to the study's findings, the ecosystem of appointment in native courts is certainly impacted by political considerations. As a consequence of the 2018 government transition, a new ministry has been created that is more focused on law and native affairs which was the Sabah's Ministry of Law and Native Affairs. As a result, modifications were made in the appointment of native court officials. Although there are difficulties to change the organisation in the native courts at first, it is also beneficial since it would facilitate the court's interaction with the ruling government.

\section{The Governance-related Issues of Native Courts}

Based on the findings of the study, there are two aspects regarding the governance of the Native Courts in Kudat and Matunggong. These have been identified as the inconsistencies in the administrative organization chart and the shortage of employees for basic services.

\section{Inconsistencies in The Organization Chart for Native Courts Administration}

Our research found substantial difference in the comparison of the two native courts' organisational charts. The Kudat Native Court has three district heads, but the Matunggong Native Court has only one district head, for example. Figures 3 and 4 illustrate this. 


\section{Kudat Native Court Organization Chart}

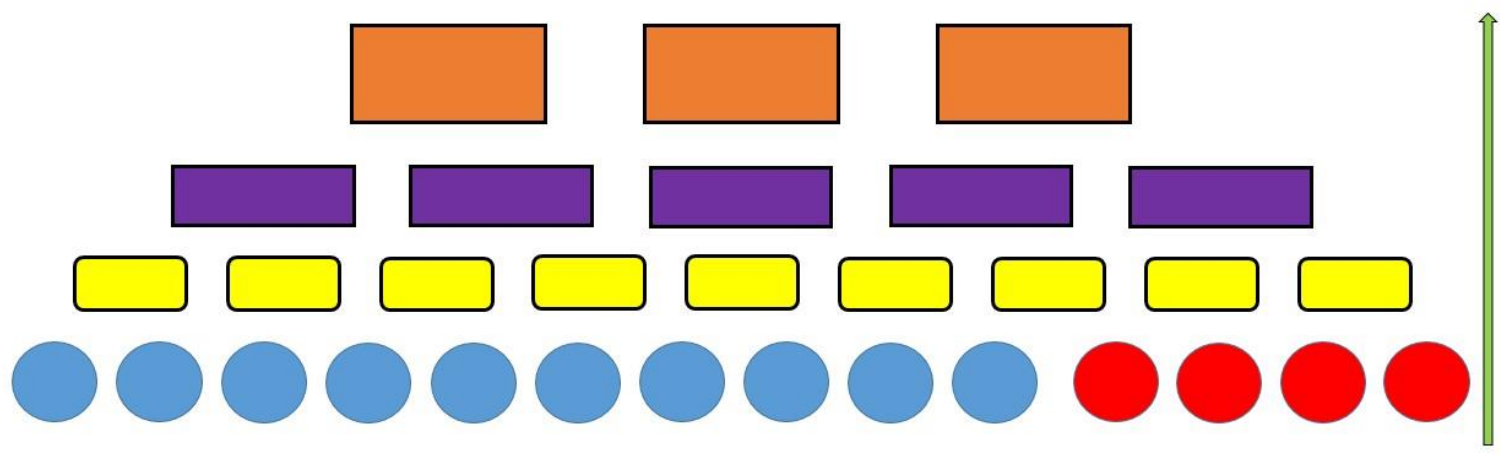

Legend

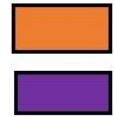

District Heads

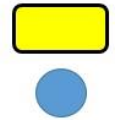

Deputy Native Chiefs

Chinese Community Leaders

Native Chiefs

Village Heads

介 Bottom-up governance

Figure 3: Kudat Native Court Organization Chart

Source: Researchers (2021)

\section{Matunggong Native Court Organization Chart}
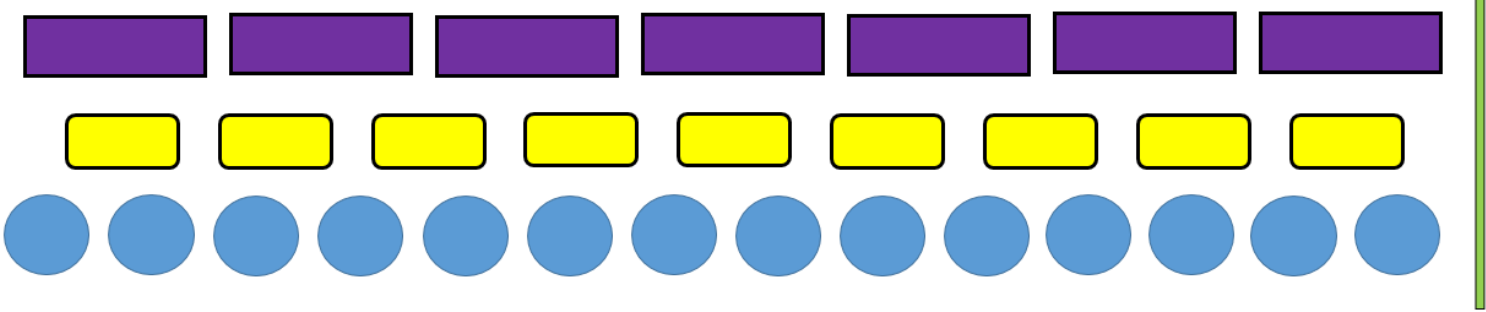

\section{Legend}
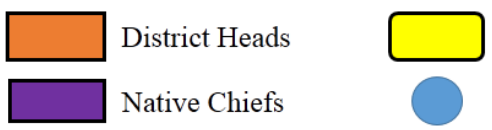

Deputy Native Chiefs

Bottom-up governance

Figure 4: Matunggong Native Court Organization Chart

According to Figures 3 and 4, the most noticeable variation in the administrative organisation of these two native courts is the number of persons holding office for each hierarchy identified in the native court system. Kudat Native Court has three district heads, but Matunggong Native 


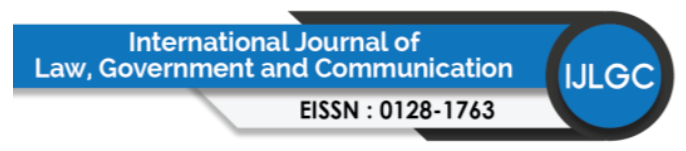

Volume 6 Issue 25 (September 2021) PP. 94-113

DOI 10.35631/IJLGC.625009

Court has just one. Furthermore, the number of native chiefs and deputy native chiefs appointed in these two native courts differs. This disparity demonstrates the inconsistency of the native court environment throughout the state of Sabah as a whole. The division of jurisdiction is particularly ambiguous in Kudat, for example, due to the appointment of several district heads. In reality, because of the duplication of authority, no one can function as a decision maker as a whole. According to Rafidah @ Malissa and Syuhaeda Aeni (2019), this is the main challenge faced by the Sabah Native Courts because the records of proceedings are rarely archived at the native chief or village head's level. In addition, evidence is given verbally in an informal manner, court judgements are typically rendered orally, and knowledge of these is limited to the district or village level further making the it difficult for the Native Court Ordinance to be sufficiently enforced (Syed Ahmad Idid, 1993).

\section{Shortage of Employees for Basic Services}

Due to a labour shortage in these two native courts, the workload of the officers in the native courts has increased. Aside from handling the affairs of the locals on a daily basis, they must also act as cleaning staff and be their own clerks to help with the day-to-day job processes. Finally, in addition to endangering the health and workload of officers in the native courts involved, this matter has an indirect impact on their motivation. This will have an indirect impact on the personnel's engaged dedication. Wang and Gupta (2001) also said that when the workload grows, employee commitment or loyalty to the company would decrease.

\section{Recommendation}

As a result of the research findings and discussions, there are several important essential aspects that need to be improved and reinforced in order for native courts to remain relevant, have a solid identity, and function effectively to fulfil the demands of natives. Judge Richard Malanjum, the Former Chief Judge of Sabah and Sarawak says native courts must undergo a change if they are to stay relevant in Sabah (Rafidah @ Malissa \& Syuhaeda Aeni, 2019). For the recommendation, authorities in the Sabah Native Court need to enhance these two elements: i) the procedure for appointing native court officials, and ii) the creation of a consistent and effective organisational framework to aid in the smooth governance of native courts in Sabah, all of which are critical.

\section{Specify the Procedure and Qualifications for Selecting Native Court Officials.}

The informants for this study have knowledge and experience limitations about customary law and native court governance. This is due to a lack of experience in performing responsibilities in the native courts, as their nominations are affected by changes in Sabah's dominant political party. Furthermore, the political instability and change of administration led in officers who had already experienced and served longer in the native courts being exchanged with new officers appointed by the dominant political party. As a result, new district heads, native chiefs, deputy native chiefs, and village heads are appointed resulting in a significant number of officials who do not have a background or expertise handling native customary issues in Sabah to be appointed. It is recommended, however, that political appointments and dismissals should never be considered in the native courts' structural ecosystem.

Instead, a guideline and qualifying requirements for the appointment of officers in the native courts must be established. The former Minister of Law and Native Affairs of Sabah (this ministry was disbanded when there was a change of Sabah Government in 2020) suggested in 2018 to reorganise the posts in the native courts by providing specific grade roles to officials 
Volume 6 Issue 25 (September 2021) PP. 94-113

DOI 10.35631/IJLGC.625009

in the Sabah native court. For example, our district heads hold Grade 41 jobs and must be Sabah indigenous people with a degree, thus we compare the native chief to a high court judge and as least have a diploma (Astro Awani, May 28, 2018). Setting these eligibility conditions is critical to enhancing the prestige of the native court as a judicial entity that is still relevant and used by natives today. "This is to ensure that the Sabah Native Court is viewed as trustworthy by the community and that all processes operate smoothly," said Datuk Aidi Haji Mokhtar. Moreover, according to Rafidah @ Malissa and Syuhaeda Aeni (2019), if the Headman, the native chief, and the district head are appointed without influence from political parties then the native court's dignity and the people's respect towards them would be preserved.

\section{Creation of A Consistent and Effective Administration Structure to Aid in The Smooth Governance of Native Courts in Sabah}

We discovered that native court governance in these two districts is at a low level due to a lack of uniformity in administrative organisations, as well as a shortage of employees in basic services such as security guards, clerks, and cleaning workers, which forces key personnel such as district heads and native chiefs to take on these tasks. This is owing to the native courts' lack of an effective and consistent administration structure. Each native court has its own administrative framework. As previously stated, there is no specific district head to serve as the court's principal leader in the Kudat native court. As a result, there is a conflict of authority between the district heads who are chosen to make administrative decisions. Furthermore, there are no designated support staff on duty to assist with secretarial work and premise maintenance. Figure 5 depicts the researcher's suggestion for an effective organisational structure that should exist in native courts. 
Volume 6 Issue 25 (September 2021) PP. 94-113

DOI 10.35631/IJLGC.625009

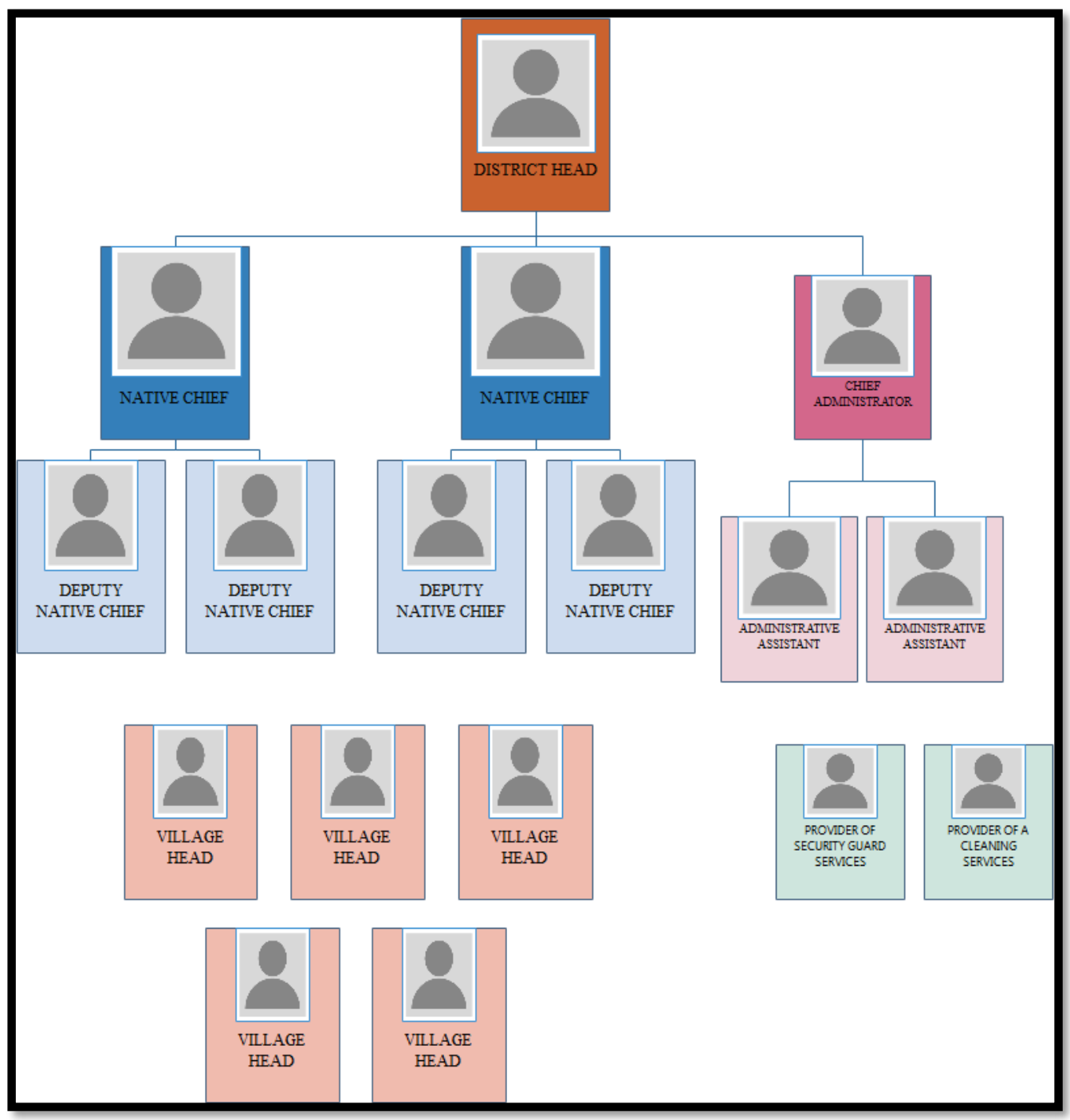

\section{Figure 5: Researchers' Suggestion for An Effective Organisational Structure for Native Courts.}

Source: Researchers (2021).

Based on Figure 5, it is clear that in order to address the issue of inefficiency in day-to-day operations in the native courts involved. Ideally, just one district head should be in charge of overall decision-making and court administration. The division of administrative tasks should be split by creating a new post, the chief administrator, who will be accompanied by two more administrative assistants. Following that, a contract tender for a security guard and cleaning service is necessary to assure the safety and cleanliness of the native court premises. With this sort of implementation, the district head, native chief, and deputy native chief are no longer doing the secretarial and cleaning duties. Indirectly, this helps to improve the quality of services given by officials in native courts since they will be more focused on their essential duty of regulating native customs matters. This is what has been suggested by (Leftwich, 1993; Leftwich 1994; Rhodes, 2000) stated that good governance refers as a method or system of governing, administering, and regulating a policy, function, or operation of a corporation, organisation (Rhodes, 2000), that involves "an efficient public service, an independent judicial system and legal framework to enforce contracts; the accountable administration of public 


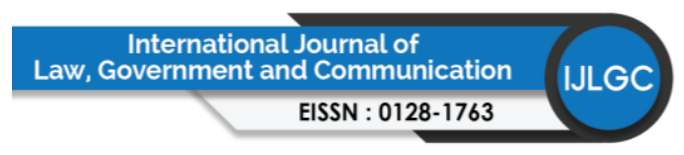

Volume 6 Issue 25 (September 2021) PP. 94-113

DOI 10.35631/IJLGC.625009

funds; an independent public auditor, responsible to a representative legislature; respect for the law and human rights at all levels of government; a pluralistic institutional structure, and a free press (Leftwich, 1993; Leftwich 1994; Rhodes, 2000).

\section{Conclusion}

To conclude, in this study on the structural environment and governance of native courts in Kudat and Matunggong districts, the researchers found that administrative features in legal institutions based on customary laws in Sabah still need to be addressed. In-depth exposure, seminars, and more regular training can all assist to improve the overall quality of the native courts. Furthermore, there is a need for the uniformity of native judicial institutions throughout the state of Sabah. Finally, for the Sabah Native Courts to be successful, the government must consider changes and improvement in employee demands for fundamental services and effective administration structure.

\section{Acknowledgements}

We would like to express our appreciation to Universiti Malaysia Sabah for providing the Special Fund Scheme (Skim Dana Khas) SDK0086-2019 that enabled us to carry out this study.

\section{References}

Ahadin Arinen. (2015). Strengthening Native Courts: An Experience of Sabah Syariah Courts. Retrieved on September 11 ${ }^{\text {th }}$, 2021, from https://erakita.wordpress.com/2015/03/07/ pemantapan-mahkamah-anak-negeri-satu-pengalaman-mahkamah-syariah-negerisabah

Asia-Pacific Human Rights Information Center. (2019). Update on Indigenous Peoples of Malaysia. Retrieved on September 11 ${ }^{\text {th }}$ 2021, from https://www.hurights.or.jp/archives/focus/section3/2019/06/update-on-indigenouspeop les-of-malaysia.html

Berita Harian. (February $\left.9^{\text {th }}, 2019\right)$. Isu anak negeri jangan sampai gugat perpaduan. Diakses pada 15 September 2020.

Dahm, Bernard. (1988). Sejarah Indonesia Abad kedua puluh. Terjemahan. Kuala Lumpur: Dewan Bahasa dan Pustaka.

Hamzah, W. A. (2018). Piracy, Paramountcry and Protectorates. Journal of Malaysian and Comparative Law, 1(2), 326-329.

Hooker, M. B. (1980). Native law in Sabah and Sarawak. Lexis Law Publishing.

James F. Ongkili (2003). The Problems of KadazanDusun Bumiputeraism: Promises, Privileges and Politics. Jurnal Kajian Malaysia, Vol. XXI, No. 1 \& 2. m.s 197-209.

Jasmi, K. A. (2012). Metodologi Pengumpulan Data dalam Penyelidikan Kualitatitif in Kursus Penyelidikan Kualitatif Siri 12012 at Puteri Resort Melaka on 28-29 Mac 2012. Organized by Institut Pendidikan Guru Malaysia Kampus Temenggong Ibrahim, Jalan Datin Halimah, 80350 Johor Bahru, Negeri Johor Darul Ta'zim.

Leftwich, A. (1993). 'Governance, Democracy and Development in the Third World', Third World Quarterly, 14: 605-24.

Leftwich, A. (1994). 'Governance, the State and the Politics of Development', Development and Change, 25: 363-86.

Lenny James Matah, Rafidah@Malissa Binti Datuk Salleh, Faiqah Binti Mawardi \& Mohammad Firdaus bin Mohamad. (2017). Native Court v. Syariah Courts in Sabah:
A Comparison.
Retrieved
September
$11^{\text {th }}, \quad 2021$,
from 


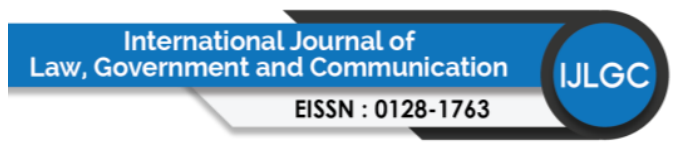

Volume 6 Issue 25 (September 2021) PP. 94-113

DOI 10.35631/IJLGC.625009

https://www.academia.edu/39802474/Mahkamah_Anak_Negeri_v._Mahkamah_Syari ah_di_Sabah_Satu_Perbandingan

Miyamoto, M. (2008). Indigenous Law and the Native Court in Sabah: A Case Study of the Penampang Kadazan. In Masaru Miyamoto \& Judeth John Baptist (eds.). Legal Culture in South-East Asia and East Africa. Sabah Museum Monograph Volume 11. Kota Kinabalu: Department of Sabah Museum, pp. 21-67.

Morton, M. F. (2017). The Rising Politics of Indigeneity in Southeast Asia. ISEAS Publishing. Mosli Tarsat (2009). Kerelevanan dan Prospek Jawatan Ketua Anak Negeri di Sabah: Satu Perspektif Sejarah. Sosiohumanika. Bil 2(2). M.s 227-250.

Muhiddin Yusin. (1990). Islam Di Sabah. Kuala Lumpur: Dewan Bahasa dan Pustaka.

Native Court Enactment 1992.

Native Courts (Criminal Jurisdiction) Act 199.

Native Courts (Native Customary Laws) Rules 1995.

Official Website of the Department of Arts \& Culture, Malaysia, 2020

Peter R. Phelan. (2003). The Traditional Legal System of Sabah, Kota Kinabalu: Pusat Kajian Borneo.

Pg Ismail Pg Musa, Siti Zubaidah Ismail \& Narizan Abdur Rahman. (2018). Amalan Sogit Ke Atas Anak Negeri Sabah Beragama Islam Di Mahkamah Anak Negeri: Kajian Dari Perspektif Hukum. Jurnal Islam Dan Masyarakat Kontemporari, 19, 1-17.

Pugh-Kitingan, J. (2015). Cultural and Religious Diversity in Sabah and Relationships with Surrounding Areas. Islam and Cultural Diversity in Southeast Asia, 269-294.

Rafidah @ Malissa Datuk Haji Salleh \& Syuhaeda Aeni Mat Ali. (2019). Study on the Administration of the Native Law in Sabah: A Need for Transformation? Accessed on 15 September 2020 from https://www.researchgate.net/publication/330602329_A_Study_on_the_Adminis tration_of_the_Native_Law_in_Sabah_A_Need_for_Transformation

Rafidah@ Malissa Datuk Hj Salleh. (2014). Native Courts System in Sabah: Will it Continue to Survive? Paperwork presented on International Conference on Law, Policy and Social Justice (ICLAPS 2014). 10th \& 11th September 2014.

Raymond Tombung. (2009). Time to end political meddling in native courts. Published in the Daily Express, on Sunday, August 23, 2009.

Regina Lim (2008). Federal-State Relations in Sabah, Malaysia. Singapore: Institute of Southeast Asian Studies.

Rhodes, R. A. W. (1997). Understanding Governance. Buckingham, Open University Press.

Rhohes, R.A.W., (2000). Governance and Public Administration. University of Southhampton, UK. https://www.researchgate.net/publication/246335680_Governance_and_Public _Administration.

Rosazman Hussin, Johan Johnes, Jabil Mapjabil, Jeannet Stephen \& Jurry Foo. (2021). Ecosystem Structural and Governance of Native Courts in Sabah. Malaysian Journal of Social Sciences and Humanities (MJSSH), 6(8), 281-292.

Sabah Native Affairs Council Enactment 1998.

Sabah State Attorney-General's Chambers. (2021). Interpretation (Definition of Native) Ordinance 1952. Retrieved on May $18^{\text {th }}$, 2021, from https://sagc.sabah.gov.my $/ \mathrm{q}=$ en/content/interpretation-definition-native-ordinance-cap-64

Syed Ahmad Idid bin Syed Abdullah Idid. (1993). Native Court and Customary Law of Sabah (With Cases and Decisions). Sabah: Government Printing Press. 
Volume 6 Issue 25 (September 2021) PP. 94-113

DOI 10.35631/IJLGC.625009

United Nations Development Programme, UNDP. (1997). Governance to Support Sustainable Human Development.

Program

Information Bulletin Partnership for Governance Reform in Indonesia.

Wang, W.Y. \& Gupta, D. (2011). Absenteeism and nurse staffing. Paper presented at the POMS 23rd Annual Conference. Available at http://www.poms meetings.org/ confproceedings/025/FullPapers 